\title{
An Economic Analysis of Development and Structure of the Foreign Total Intra-Arab Trade
}

\author{
Tarek T. El Khateeb1, Sarhan A. A. Soliman², Roshdy S. Eladawy ${ }^{3}$ \\ ${ }^{1}$ Department of Agricultural Economics, Kafr Elsheikh University, Egypt, \\ ${ }^{2}$ Agricultural Economy Research Institute, Agricultural Research Center, Egypt \\ ${ }^{3}$ Agricultural Economic, Faculty of Agriculture, Kafr El-Sheikh University, Egypt \\ Email: tkhteb@yahoo.com, sarhansoliman@yahoo.com
}

Received 3 September 2015; accepted 25 January 2016; published 28 January 2016

Copyright (C) 2016 by authors and Scientific Research Publishing Inc.

This work is licensed under the Creative Commons Attribution International License (CC BY). http://creativecommons.org/licenses/by/4.0/

(c) (†) Open Access

\begin{abstract}
The foreign intra-Arab trade is an essential tool and important input in order to achieve an important Arab economic integration. However, in spite of the efforts for the Liberation of the Arab Trade and Development, the fact indicates the modest rate of the foreign intra-Arab trade to the foreign total Arab trade with the world, as it does not exceed that percentage to $10.9 \%$ in year 2013 . The present research is aimed at measuring the efficiency of the total foreign intra-Arab trade during the period (1990-2010). Where, it has been increased sharply, as value of the total foreign intraArab trade increases annually by about 12.6\%. Saudi Arabia and United Arab Emirates are considered the most important contributors of the total foreign intra-Arab trade, and a category of manufacturing has dominated the largest relative importance in average value of total Arab trade, which has accounted to $\mathbf{5 0 . 8 \%}$. Followed by category, metal fuel and other metals are accounted by about $\mathbf{2 5 . 3 \%}$ and there is lower overall contribution to the foreign intra-Arab trade in the total foreign trade of Arab and its amount has increased by $\mathbf{1 0 . 5 8 \%}$. Therefore, it is recommended to further coordination among the Arab States in the areas of production and specialization in economic production. This is also recommended to establish the specialized department for greater Arab free trade area in every Arab country in addition to accelerate the establishment of a customs union.
\end{abstract}

\section{Keywords}

International Trade, INTRA-Arab Trade, Structure of Arab Trade, GAFTTA

\section{Introduction}

Since the foundation of The League of Arab States in 1945, Arab countries have established a number of proce- 
dures with an aim to develop the common economic Arab work generally and development of the total intraArab trade particularly. The latest was the Convention on the Great Arab Free Trade area, which was also known as "GAFTTA" in year 1998. It entered into the implementation to come into effect in year 2005. A model of Arab integration and free access to trade between Arab countries has established. That may lead to the opening Arab markets, eliminating tariff and non-tariff barriers to remove obstacles in trade and also to facilitate the transit and transportation of goods [1].

The implementation of the Convention process steps is completed with liberalization of trade between Arab countries under the trade liberalization at the global level, and under the umbrella of the International Trade agreements and World Trade Organization (WTO). That reflects the evolution of intra-Arab trade and its growth. Where, there are many of the reasons and motives, whether internal or external, that justifies the development of intra-Arab trade. Perhaps, from those reasons at the international level, the orientation has moved toward economic blocs and changes in the global economic system [2]. The most importantly, the motive on the Arab level consists in orientation toward the economy, the market and the burden of external debt for many of the Arab States. Moreover, the main ingredients are available to achieve economic integration among Arab countries [3].

In addition, the intra-Arab trade is an essential tool and input in order to achieve an important Arab economic integration. In spite of the efforts to liberate the Arab trade and development, the fact refers to modest proportion of the intra-Arab trade to the foreign total trade with the world. As it has not exceeded $11.5 \%$ in year 2010 and Arab countries are importing more than $90 \%$ of its needs from abroad [1] [4], the adoption of the Arab world in securing its needs on the world markets involves some risks in light of the changes and developed world [5] [6].

\subsection{Research Problem}

The Arab countries attempt to improve the position of the foreign total intra-trade of Arab including a number of free trade agreements, to facilitate the movement of exports and imports and including a reduction in tariffs, and non-tariff restrictions on the imports from other Arab countries various forms. However, the application of the Convention on the Great Arab Free Trade Area has not increased total intra-Arab trade after the application of the Convention, and that the rate of increase in the region is still weak compared to their peers in the limits of international economic groupings.

\subsection{Research Objectives}

The study attempts to analysis the development and structure of the foreign total intra-Arab trade, in light of the implementation of the Great Arab Free Trade Area "GAFTTA". This has necessitated the need to study and to analyze the development of the total intra-Arab trade. In addition, we will do the analysis of total intra-exports and imports of Arab countries, and the contribution of Arab countries in this trade, as well as rates of change annual the intra-trade Arab countries during the period (1990-2010).

\subsection{Research Method}

The present research adopts the descriptive and quantity methods to study of development and the structure of the foreign total intra-Arab trade, total intra-exports and imports Arab, the contribution of Arab countries in this trade and annual rates of change in the intra-trade Arab countries.

\subsection{Data Sources}

This research is based on the published data of public administration, economic affairs of the League of Arab States, the Arab Organization for agricultural development, the Arab Monetary Fund, the Secretariat of the Council of Arab economic unity, Economic bulletin National Bank of Egypt, the Food and Agriculture Organization of the United Nations (FAO), the World Bank, Economic Affairs of the Ministry of Agriculture and the Central Agency for Public Mobilization and Statistics. In addition, some data and statistics published by some on the international information network "Internet" has also been taken.

\section{Results}

\subsection{Development of the Total Intra-Arab Trade}

The average value of the total intra-Arab trade during the period of (1990-2010) has remained at 61.89 Billion 
Dollars. It is varying from a minimum value of about 19.71 Billion Dollars in year 1991 with a record number of about $82.02 \%$ compared to the base year (1990) and a maximum value of about 182.3 Billion Dollars in year 2008 with a total increase by $758.51 \%$ compared to the base year (1990) (Table 1 ).

The estimates of the equation of the time trend of the evolution of the value of the total intra-Arab trade during the period of study, as in the Equation (1), Table 2, the coefficient of annual statistical signification at the level of (0.01) reaches about 7.2 billion dollars. That represents about $11.6 \%$ of the annual average, and shows the value of the parameter selection $\left(\mathrm{T}^{2}\right)$ to about $62.6 \%$ of the changes in the value of total intra-Arab trade due to factors reflect the effects of time.

Table 1. Development of the value of total intra-Arab trade and the total intra-Arab trade balance during the period (19902010). Value: by billion US dollars.

\begin{tabular}{|c|c|c|c|c|c|c|c|}
\hline \multirow{2}{*}{ Statement } & \multicolumn{2}{|c|}{ Total intra-Arab trade } & \multicolumn{2}{|c|}{ Total intra-Arab exports } & \multicolumn{2}{|c|}{ Total intra-Arab imports } & \multirow{2}{*}{$\begin{array}{c}\text { Total intra-Arab } \\
\text { trade balance } \\
\text { Value }\end{array}$} \\
\hline & Value & Relative number & Value & Relative number & Value & Relative number & \\
\hline 1990 & 24.03 & 100.00 & 13.78 & 100.00 & 10.25 & 100.00 & 3.53 \\
\hline 1991 & 19.71 & 82.02 & 10.55 & 76.57 & 9.16 & 89.35 & 1.39 \\
\hline 1992 & 21.65 & 90.06 & 11.07 & 80.34 & 10.57 & 103.12 & 0.50 \\
\hline 1993 & 22.28 & 92.71 & 11.08 & 80.42 & 11.20 & 109.24 & $(0.12)$ \\
\hline 1994 & 23.38 & 97.28 & 11.79 & 85.56 & 11.59 & 113.04 & 0.20 \\
\hline 1995 & 26.61 & 110.73 & 13.72 & 99.58 & 12.89 & 125.72 & 0.83 \\
\hline 1996 & 28.64 & 119.14 & 14.84 & 107.65 & 13.80 & 134.59 & 1.04 \\
\hline 1997 & 30.44 & 126.66 & 15.56 & 112.92 & 14.88 & 145.13 & 0.68 \\
\hline 1998 & 27.30 & 113.58 & 14.02 & 101.76 & 13.28 & 129.48 & 0.75 \\
\hline 1999 & 28.90 & 120.26 & 14.29 & 103.70 & 14.61 & 142.51 & $(0.32)$ \\
\hline 2000 & 32.94 & 137.04 & 16.77 & 121.67 & 16.17 & 157.69 & 0.60 \\
\hline 2001 & 36.90 & 153.52 & 18.53 & 134.44 & 18.37 & 179.17 & 0.16 \\
\hline 2002 & 40.46 & 168.34 & 20.32 & 147.46 & 20.14 & 196.42 & 0.18 \\
\hline 2003 & 47.13 & 196.08 & 22.81 & 165.52 & 24.31 & 237.14 & (01.5) \\
\hline 2004 & 64.08 & 266.61 & 34.67 & 251.54 & 29.41 & 286.87 & 5.25 \\
\hline 2005 & 92.37 & 384.34 & 48.27 & 350.29 & 44.10 & 430.10 & 4.18 \\
\hline 2006 & 111.99 & 465.96 & 58.56 & 424.92 & 53.43 & 521.12 & 5.13 \\
\hline 2007 & 134.77 & 560.76 & 70.73 & 513.21 & 64.05 & 624.67 & 6.68 \\
\hline 2008 & 182.30 & 758.51 & 95.41 & 692.34 & 86.89 & 847.44 & 8.52 \\
\hline 2009 & 149.50 & 622.05 & 76.99 & 558.70 & 72.51 & 707.20 & 4.48 \\
\hline 2010 & 154.37 & 642.28 & 77.74 & 564.13 & 76.62 & 747.33 & 1.12 \\
\hline Average & 61.89 & & 31.98 & & 29.92 & & 2.06 \\
\hline
\end{tabular}

Volume in brackets is negative. Source: collected and calculated from: 1. The League of Arab States, Arab Monetary Fund, Unified Arab Economic Report, various issues. 2. World Bank, World Development Indicators, various periods. 
Table 2. Equations time trend of the Development of the value of total intra-Arab trade during the period (1990-2010).

\begin{tabular}{|c|c|c|c|c|c|c|}
\hline No. equations Statement & $\begin{array}{c}\text { The dependent } \\
\text { variable } \hat{y_{t}}\end{array}$ & Estimated equations & $\begin{array}{l}\text { The annual } \\
\text { average }\end{array}$ & $\begin{array}{c}\text { Annual rate of } \\
\text { change } \%\end{array}$ & R2 & $\mathrm{F}$ \\
\hline (1) & $\begin{array}{l}\text { value of the total } \\
\text { intra-Arab trade }\end{array}$ & $\begin{array}{c}y_{t}^{\wedge}=-14.143+7.193 x_{t} \\
\quad(0.927-) *(5.640)\end{array}$ & 61.89 & 11.6 & 0.63 & *31.807 \\
\hline (2) & $\begin{array}{l}\text { value of the total } \\
\text { intra-Arab exports }\end{array}$ & $\begin{array}{c}y_{t}^{\wedge}=-7.468+3.731 x_{t} \\
(0.940-) *(5.622)\end{array}$ & 31.98 & 11.7 & 0.63 & *31.666 \\
\hline (3) & $\begin{array}{l}\text { value of the total } \\
\text { intra-Arab imports }\end{array}$ & $\begin{array}{c}y_{t}^{\hat{t}}=-6.677+3.462 x_{t} \\
(0.908) *(5.636)\end{array}$ & 27.69 & 11.6 & 0.63 & *31.766 \\
\hline (4) & $\begin{array}{c}\text { The Total intra-Arab } \\
\text { trade balance }\end{array}$ & $\begin{array}{c}y_{t}^{\wedge}=-0.790+0.270 x_{t} \\
(0.722-) *(3.577)\end{array}$ & 2.06 & 34.4 & 0.64 & $* 9.972$ \\
\hline
\end{tabular}

$y_{t}^{\wedge}$ : The estimated value of the dependent variable indicated billion dollars in a year $t . \quad x_{t}$ : Variable of time by a year. $t=1.2,3, \cdots, 21$. Values in brackets refer to the values of $(\mathrm{T})$ calculated. * significant at $(0.01),{ }^{* *}$ significant at $(0.05)$. Source: 1 . Collected and calculated from: The Arab League, Arab Monetary Fund, Unified Arab Economic Report, various issues. 2. World Bank data, World Development Indicators, various periods.

\subsection{Relative Importance of the Total Intra-Trade for Arab Countries}

It is clear that Saudi Arabia has captured the first center, as the largest contribution to the value of the total intra-Arab trade. The relative importance of the value of the total intra-trade of Saudi Arabia has mounted by $25.2 \%$ of the average value of the total intra-Arab trade. Followed by the United Arab Emirates, that is about $13.5 \%$. The next order of countries are Oman, Iraq, Egypt, Bahrain, Jordan, Syria, Kuwait, and Morocco in the centers of the third to tenth by relative importance of about $7.4 \%, 6.5 \%, 6.4 \%, 5,4 \%, 5.2 \%, 4.8 \%, 3,8 \%$ and $3.6 \%$ of the average value of total intra-Arab trade respectively. The relative importance of the total intra-trade of these ten countries is about $82 \%$ of the average value of the total intra-Arab trade during the same study period (Table 3 ).

These results indicate of Saudi Arabia and the United Arab Emirates are considered the most important contributor to the total intra-Arab trade, as taken together about 38.9\% of the average of the total intra-Arab trade value during the period of study.

\subsection{Annual Rates of Change to the Total Intra-Trade for Arab Countries}

An assessment shows the trend of the equations of the value of the total intra-Arab trade countries during the period of the study (1990-2010). It can be seen that the countries of Comoros, Iraq, Egypt, Qatar, Syria, Yemen, Sudan, Somalia, the United Arab Emirates, Kuwait, Saudi Arabia, Jordan, Algeria, and Oman have achieved high rates of annual increase (10\% or more), with the value of $20 \%, 16.5 \%, 15.8 \%, 14 \%, 13.2 \%, 12.4 \%, 12.3 \%$, $11.9 \%, 11.9 \%, 11.8 \%, 11.8 \%, 11.7 \%$, be $11.4 \%, 10 \%$ of the annual averages of the value of the total intra-trade respectively. In case of Tunisia, Morocco, Lebanon, Bahrain, Djibouti, and Libya, rates of average annual have increased by about (5\% - less than 10\%), with the estimated values of $9.4 \%, 9.3 \%, 8.8 \%, 8.1 \%, 7 \%$, 5.8\% of annual averages of the value of the total intra-trade respectively. On the other hand, Mauritania has a low annual rate of increase (less than 5\%) in the value of the inter-trade as estimated at about $4 \%$ of the annual average of the value of the total intra-trade (Table 4).

These results indicate that the countries of each of the Comoros, and Syria are the two countries in achieving higher rates of annual increase in the value of the total inter-trade with other Arab countries. Mauritania is the country at least in the annual rates of increase in the value of the total intra-trade with the rest of the Arab countries during the study period.

\subsection{Development of the Total Intra-Arab Exports}

The average value of the total intra-Arab exports during the period of study is recorded at about 31.98 billion dollars. That is varying between a minimum value of about 10.55 Billion Dollars in year 1991, with a record number of about 76.56\% compared to the base year, and a maximum of about 95.41 Billion Dollars in year 2008, with a total increase in 692.34\% compared to the base year (Table 1).

The estimates of the equation of the time trend of the evolution of the value of total intra-Arab exports during the period of the study are shown in the Equation (6), Table 2. The coefficient of annual statistical at the level of (0.01) has reached about 3.73 billion dollars, representing about $11.7 \%$ of the annual average. Moreover, it shows the value of the parameter Selection $\left(\mathrm{T}^{2}\right)$ that is about $62.5 \%$ of the changes in the value of total intraArab exports due to factors reflect the effects of time. 
Table 3. Development of relative importance contribution of Arab countries in the total foreign intra-Arab trade during the period (1990-2010). Value by billion dollars.

\begin{tabular}{|c|c|c|c|c|c|c|c|}
\hline \multirow{2}{*}{ Statement } & \multicolumn{2}{|c|}{ Total intra-Arab trade } & \multicolumn{2}{|c|}{ Total intra-Arab exports } & \multicolumn{2}{|c|}{ Total intra-Arab imports } & \multirow{2}{*}{$\begin{array}{c}\text { Total intra-Arab } \\
\text { balance trade } \\
\text { The value }\end{array}$} \\
\hline & The value & $\begin{array}{l}\text { Relative } \\
\text { importance }\end{array}$ & The value & $\begin{array}{l}\text { Relative } \\
\text { importance }\end{array}$ & The value & $\begin{array}{l}\text { Relative } \\
\text { importance }\end{array}$ & \\
\hline Jordan & 3.20 & 5.17 & 1.15 & 3.59 & 2.05 & 68.6 & 0.90 \\
\hline Emirates & 8.38 & 13.54 & 5.22 & 16.33 & 3.16 & 10.56 & 2.06 \\
\hline Bahrain & 3.34 & 5.40 & 1.02 & 3.18 & 2.32 & 7.77 & 1.31 \\
\hline Tunisia & 1.59 & 2.57 & 0.75 & 2.34 & 0.84 & 2.80 & 0.09 \\
\hline Algeria & 1.21 & 1.96 & 0.67 & 2.11 & 0.54 & 1.80 & 0.14 \\
\hline Djibouti & 0.20 & 0.33 & 0.07 & 0.21 & 0.14 & 0.46 & 0.07 \\
\hline Saudi Arabia & 15.58 & 25.17 & 12.19 & 38.12 & 3.39 & 11.33 & 8.80 \\
\hline Sudan & 1.24 & 2.01 & 0,36 & 1.12 & 0.88 & 2.95 & 0.52 \\
\hline Syria & 2.96 & 4.78 & 2.04 & 6.39 & 0.91 & 3.05 & 1.13 \\
\hline Somalia & 0.32 & 0.51 & 0.16 & 0.50 & 0.16 & 0.52 & 0.004 \\
\hline Iraq & 3.99 & 6.45 & 0.70 & 2.18 & 3.29 & 11.01 & 2.60 \\
\hline Amman & 4.56 & 7.37 & 2.00 & 6.24 & 2.57 & 8.58 & 0.57 \\
\hline Qatar & 2.00 & 3.24 & 0.77 & 2.39 & 1.24 & 4.14 & 0.47 \\
\hline Kuwait & 2.32 & 3.75 & 0.84 & 2.62 & 1.49 & 4.96 & 0.65 \\
\hline Lebanon & 1.63 & 2,63 & 0.65 & 2.03 & 0.98 & 3.27 & 0.33 \\
\hline Libya & 1.32 & 2.14 & 0.68 & 2.12 & 0.64 & 2.16 & 0.03 \\
\hline Egypt & 3.95 & 6.38 & 1.91 & 5.98 & 2.03 & 6.8 & 0.12 \\
\hline Morocco & 2.21 & 3.57 & 0.41 & 1.29 & 1.80 & 6 & 1.38 \\
\hline Mauritania & 0.05 & 0.08 & 0.01 & 0.02 & 0.04 & 0.15 & 0.04 \\
\hline Yemen & 1.82 & 2.94 & 0.38 & 1.19 & 1.44 & 4.81 & 1.06 \\
\hline Comoros & 0.02 & 0.03 & 0.01 & 0.04 & 0.008 & 0.03 & 0.006 \\
\hline Total & 61.89 & 100 & 31.98 & 100 & 29.92 & 100 & 2.06 \\
\hline
\end{tabular}

Source: collected and calculated from: 1. The League of Arab States, Arab Monetary Fund, Unified Arab Economic Report, various issues. 2. World Bank, World Development Indicators, separate periods.

\subsection{Relative Importance of the Total Intra-Exports for Arab Countries}

It is cleared that Saudi Arabia come in the first center, as the largest contribution country in the total intra-Arab exports contribution, where the contribution of the value of the total intra-exports to Saudi Arabia mounted by about $38.1 \%$ of the average value of the total intra-Arab exports. Followed by the United Arab Emirates, that is a relative importance of about $\mathbf{1 6 . 3 \%}$. Then Syria, Jordan, Egypt, Jordan, Bahrain, Kuwait, Qatar, and Tunisia come in the centers of the third to tenth relative importance of about $6.4 \%, 6.2 \%$ and $6 \%, 3.6 \%, 3.2 \%, 2.6 \%, 2.4 \%$ and $2.33 \%$ respectively. The contribution of these ten countries is about $87 \%$ of the average value of total intra-Arab exports during the period of the study (Table 3).

These results indicate that Saudi Arabia and the United Arab Emirates are considered the most important Arab countries contribution, where the value of total intra-Arab exports are taken together at about $54.4 \%$ of the average value of total intra-Arab exports during the period of the study. This is due to the adoption of their total intra-exports of mineral fuel, in accordance with relative distribution of the structure of their exports. 
Table 4. Annual rates of change of the total value of the intra-trade for countries Arab during the period (1990-2010).

\begin{tabular}{|c|c|c|c|c|}
\hline Statement & Total intra-Arab trade & Total intra-Arab exports & Total intra-Arab imports & Total intra-Arab balance trade \\
\hline Jordan & 11.7 & 10.5 & 12.3 & (14.6) \\
\hline Emirates & 11.9 & 12.2 & 11.4 & 13.4 \\
\hline Bahrain & 1.8 & 10.6 & 5.8 & 1.2 \\
\hline Tunisia & 9.4 & 2.9 & 9.6 & (13.3) \\
\hline Algeria & 11.4 & 12.7 & 10 & 20 \\
\hline Djibouti & 7 & 5.7 & 6.4 & (7.1) \\
\hline Saudi Arabia & 11.8 & 12 & 11 & 12.4 \\
\hline Sudan & 12.3 & 12.5 & 12 & (11.7) \\
\hline Syria & 13.2 & 12.8 & 14.4 & 11.4 \\
\hline Somalia & 11.9 & 1.8 & 15.6 & (125) \\
\hline Iraq & 16.5 & 5.9 & 18.7 & (22.1) \\
\hline Amman & 10 & 10 & 10 & (4.6) \\
\hline Qatar & 14 & 11.7 & 15.2 & (20.9) \\
\hline Kuwait & 11.8 & 13.3 & 10.9 & 0.9 \\
\hline Lebanon & 8.8 & 9.5 & 3.8 & (5.5) \\
\hline Libya & 5.8 & 6.9 & 4.5 & 56.7 \\
\hline Egypt & 15.8 & 16.5 & 15.2 & (47.5) \\
\hline Morocco & 9.3 & 3.7 & 23.9 & (12.7) \\
\hline Mauritania & 4 & 10 & 2.5 & $(0.1)$ \\
\hline Yemen & 12.4 & 13.7 & 12.1 & (11.5) \\
\hline
\end{tabular}

Volume in brackets is negative. Source: collected and calculated from: 1. The League of Arab States, Arab Monetary Fund, Unified Arab Economic Report, various issues. 2. World Bank, World Development Indicators, separate periods.

\subsection{Annual Rates of Change to the Total Intra-Exports for Arab Countries}

An assessment shows the time trend equations of the total value of intra-exports for Arab countries during the period of the study. It has found that the countries Comoros, Egypt, Yemen, Kuwait, Syria, Algeria, Sudan, United Arab Emirates, Saudi Arabia, Qatar, Bahrain, Jordan, Oman, and Mauritania have achieved high rates of annual increase (10\% or more), with a value of which is estimated at about $30 \%, 16.5 \%, 13.7 \%, 13.3 \%, 12.8 \%$, $12.7 \%, 12.5 \%, 12.2 \%, 12 \%, 11.77 \%, 10.6 \%, 10.5 \%, 10 \%, 10 \%$ of the annual averages of the total value of intra-exports for each of them, respectively. While Lebanon, Tunisia, Somalia, Libya, and Iraq have achieved rates of annual increase (5\% - less than $10 \%$ ), with a value of estimated of $9.5 \%, 9.2 \%, 8.1 \%, 6.9 \%$, 5.9\% of annual averages of the total value of total exports respectively. While, Morocco has achieved low annual rate of increase (less than $5 \%$ ), by the value of their intra-exports is estimated at about $3.7 \%$ of the annual average of the total value of intra-exports (Table 2).

\subsection{Development of the Total Intra-Arab Imports}

The average value of total intra-Arab imports during the period of study has mounted to 31.98 billion dollars. A ranged between a low of about 9.16 Billion Dollars in year 1991 is recorded with a record number of about 89.35\% compared to the base year. And a maximum of about 86.89 Billion Dollars in year 2008 is recorded with a total increase in $847.44 \%$ compared to the base year (Table 1 ).

The estimates to the equation of time trend of the development of the value of total intra-Arab imports during 
the period of the study, as the Equation (3) (Table 2), are showing that the coefficient by an annual statistical moral at the level of moral (0.01) amounted to about 3.47 billion dollars. That is representing about $11.6 \%$ of the annual average. And it shows the value of the parameter Selection $\left(\mathrm{T}^{2}\right)$ to about $62.6 \%$ of the changes in the value of total intra-Arab imports due to factors reflecting the effects of time.

\subsection{Relative Importance of the Total Intra-Imports for Arab Countries}

Saudi Arabia comes on the first place, with the greatest relative importance in the total intra-Arab imports, where the relative importance of the value of its total intra-imports amounted by about $11.3 \%$ of the average value of the total intra-Arab imports. Followed by Iraq of the importance of relative is estimated at about $11 \%$. Then the countries the United Arab Emirates, Oman, Bahrain, Jordan, Egypt, Morocco, Kuwait, and Yemen come in the centers of the third to tenth relative importance of about $10.6 \%, 8.9 \%, 7.8 \%, 6.9 \%, 6.8 \%, 6 \%, 5 \%$, $4.8 \%$ respectively. The contribution of these ten countries remains about $79 \%$ of the average value of the total intra-Arab imports.

The previous findings show that each of the two countries of Saudi Arabia, and Iraq are considered the most important contributor to the total intra-Arab imports, while the Comoros, and Mauritania have less contribution, by relative importance of about $0.03 \%$ and $0.15 \%$ of the average value of the total intra-Arab imports for each respectively during the period of study (Table 3).

\subsection{Annual Rates of Change to the Total Intra-Imports for Arab Countries}

The time trend equations of the value of the total intra-imports for Arab countries during the period of the study shows that Morocco, Iraq, Somalia, Egypt, Qatar, Syria, Comoros, Jordan, Yemen, Sudan, Emirates, Saudi Arabia, Kuwait, Algeria, and Oman have achieved high rates of annual increase (10\% or more). with a value of which was estimated at $23.9 \%, 18.7 \%, 15.6 \%, 15.2 \%, 15.2 \%, 14.4 \%, 12.55 \%, 12.33 \%, 12.11 \%, 12 \%, 11.4 \%$, $11 \%, 10.9 \%, 10 \%, 10 \%$ of the annual averages of value of the total intra-imports respectively.

While the countries like Tunisia, Lebanon, Bahrain, and Djibouti have achieved average annual rates of increase (5\% - less than 10\%). The estimated are remained at 9.6\%, 8.3\%, $6.4 \%$ and $5.8 \%$ of annual averages of value of the total intra-imports respectively. While the countries of Libya and Mauritania have achieved low annual rate of increase (less than 5\%) and by $4.5 \%$, $2.5 \%$ of the annual average of value of total their intra-imports (Table 4).

Previous results indicate that all of Morocco, and Iraq have achieved the highest annual increase in the value of their total intra-imports with the other of the Arab countries, while the less than those rates of per state Mauritania during the study period.

\subsection{Development of the Total Intra-Arab Trade Balance}

It is clear that the value of total intra-Arab trade balance during the period of the study has remained mixed between surplus and disability. It has varied between a minimum of approximately $(-1.50)$ Billion Dollars (deficit) in year 2003, and a maximum of about 8.52 Billion Dollars (surplus) in year 2008 with an average of annual rate of about 2.06 Billion Dollars (surplus) for the same period of study (Table 1). By estimated the time trend equation of the evolution of the value of the total intra-Arab trade balance during the period of the study, it is clear that it has been a trend toward an increasing surplus annual rate of significant statistically at the level of (0.01) has reached about $13.1 \%$ of the annual average of about 2.06 billion dollars. As well as, the value of the parameter Selection $\left(\mathrm{T}^{2}\right)$ that the factors which are interpreted by the time factor is responsible for about $34.4 \%$ of the changes in the value of total intra-Arab trade balance, as Equation (10) (Table 2).

\subsection{Commodity Structure of the Total Intra-Arab Trade}

The category of manufactures is dominated the largest relative importance in average value of total intra-Arab trade, where the relative importance toward to about $54.25 \%$. Followed by a category, metal fuel other minerals about $23.99 \%$. Then categories of agricultural commodities, basic manufactures, machinery and transport equipment, chemical materials, artifacts are following. In a variety of other centers from the third to the seventh relative importance of about $18.35 \%, 18.05 \%, 15.25 \%, 13.45 \%$ and $7.5 \%$ of the average value of total intraArab trade respectively during the period of study (Table 5). 
Table 5. Development of relative distribution of total intra-Arab trade structure as an average for the period (1990-2010).

\begin{tabular}{|c|c|c|c|}
\hline Commodity & Total intra-Arab trade & Total intra-Arab exports & Total intra-Arab imports \\
\hline Agricultural commodities & 35.18 & 16.50 & 20.20 \\
\hline Mineral fuel other metals & 9.23 & 26.80 & 21.00 \\
\hline Manufactures & 54.25 & 52.20 & 56.30 \\
\hline Chemical materials & 45.13 & 11.30 & 15.60 \\
\hline Basic artifacts & 5.18 & 18.90 & 17.20 \\
\hline Machinery and transport equipment & 25.15 & 17.00 & 14.90 \\
\hline Other miscellaneous & 5.7 & 6.40 & 8.60 \\
\hline Goods not classified & 3.50 & 4.50 & 2.50 \\
\hline Total & 100 & 100 & 100 \\
\hline
\end{tabular}

Depends on the expense of the commodity structure intra-trade on the basis of standard international trade classification sitcrev3-3. Source: Compiled and calculated from: The League of Arab States, Arab Monetary Fund, Unified Arab Economic Report, various issues.

It also shows that the category of Manufactures is taking the first place in the structure of the total intra-Arab exports, where total contribution to about $52.2 \%$ of the average value of total intra-Arab exports. Manufactures are included each of chemical materials, basic manufactures, machinery and transport equipment, as well as a variety of other artifacts to non-classified, the relative importance of those components to about $11.3 \%, 18.9 \%$, $15.66 \%, 6.4 \%$ of the average value of total intra-Arab exports respectively. Followed by category metal fuel minerals which relative importance of about $26.8 \%$ while the agricultural goods in the third relative importance of about $16.5 \%$ of the average value of total intra-Arab exports during the study period (Table 5).

It also indicates that the category of Manufactures is taking a first place in the structure of the total intra-Arab imports, where total contribution to about $56.3 \%$ of the average value of the total intra-Arab imports. Manufactures are included all of chemical materials, basic manufactures, machinery and transport equipment, as well as a variety of other artifacts to non-classified, contributions amounted to those components to about $15.6 \%, 17.2 \%$, $14.9 \%, 8.6 \%$ of the average value of total intra-Arab imports. Followed by category, metal fuel and other minerals, and agricultural commodities are of relative importance of about $21 \%, 20.2 \%$, respectively, during the period of study (Table 5).

Previous results indicate that the decline in the number of goods that are being circulated among the total intra-Arab total, and perhaps this is due to the similarity of most productive structures of Arab countries, and those of the most important problems that stand in the way inter-Arab trade. Corresponds to the production of goods, reduce the terms of trade, and imposes on the Arab countries to meet their needs direction out of goods, which is not an Arab. Where it refers to the high proportion of mineral, fuel other minerals. This is due to the adoption of the States of the Gulf Arab countries and some other oil trade in the oil. That constitutes the majority of the foreign trade, therefore must be to those countries research in cooperation and coordination with the other Arab countries in the diversity of non-oil commodity production and trade.

While agricultural commodities retreated to the third position within the structure of the trade, which imposes on the Arab countries, need for coordination in the productive policy agricultural commodities, for particular importance for food security, and reduces the burden of import from abroad. In the light of the possession of Arab States elements of higher degrees of self-sufficiency and joint gains in the agricultural field, the implementation of the convention on the Great Arab Free Trade Area of critical importance, for cooperation between Arab countries to increase goods to be exchanged on the one hand. In addition, coordination between the economies of the Arab States is required to achieve greater self-sufficiency, and to reduce dependence on the outside.

\section{Conclusions}

The total Arab foreign trade is amounted to about $62.5 \%$ of the total Gross Domestic product of all Arab countries during the years (1990-2010). This means that foreign trade is a major part of the Arab Economy and a main development contributor in the Arab countries. The gradual implementation of the Great Arab free trade Area (GAFTTA) had begun in year 1998, and by year 2005 all taxes and customs tariffs among the countries 
joining the free trade Area were completely cancelled. However, the growth of Inter-Arab trade does not match this gradual cancellation of taxes and custom duties. In fact, it has not exceeded about $11 \%$ of the total Arab trade. This means that the cancellation of customs restrictions alone does not automatically lead to the growth of inter-Arab trade. There is a host of obstacles and barriers-not related to customs-preventing the desired growth. These obstacles are identified, classified, and analyzed in this paper. Some suggestions were given that might solve these obstacles. It is also presented the problem of this study that is evidenced by the intra-Arab trade and it is facing a variety of obstacles that prevent the efficient utilization of this sector in maximizing economic efficiency. The study is aimed to analyze the total intra-Arab trade during the period (1990-2010). To identify the important problems and obstacles facing intra-Arab trade, the study has employed several descriptive and analytical techniques to achieve its aims, those include simple regression. In order to achieve the objectives of the study, data have been collected from various resources such as CAPMS, yearly statistical book, foreign trade publications, the league of Arab states, Arab organization for agricultural development, the Arab currency fund, ministry of agriculture, F.A.O, and internet.

The results dealing with the intra-Arab total trade during the period (1990-2010) show that the average value of the total intra-Arab total trade has been 61.9 billion American dollars with an annual increase of about $11.6 \%$. The main contributors to total Arab foreign trade are Kingdom of Saudi Arabia (25.2\%), and United Arab Emirates (13.5\%). The average value of the total intra-Arab total exports has accounted by 31.9 billion American dollars with annual increase of about $11.7 \%$ during the study period. The main contributors to total intra-Arab total exports has remained Kingdom of Saudi Arabia (38.1\%), and United Arab Emirates (16.3\%), while the average value of the total intra-Arab total imports has remained 29.9 billion American dollars with annual increase of about $11.6 \%$. The main contributors to total intra-Arab total imports have remained Kingdom of Saudi Arabia (11.3\%), and Iraq (11\%) during the study period. The total intra-Arab total trade balance has shown an average surplus of about 2.1 billion American dollars with an annual increase of about $13.1 \%$. The countries that have the greatest surplus are Saudi Arabia (8.8 billion dollars), United Arab Emirates (2.1 billion dollars), Syria (1.1 billion dollars), Algeria ( 0.14 billion dollars), and Libya ( 0.03 billion dollars). On other hand, the countries that have remained in the greatest deficit are Iraq (2.6 billion dollars), Morocco (1.4 billion dollars), Bahrain (1.3 billion dollars), Yemen (1.1 billion dollars), and Jordan (0.9 billion dollars) during the study period. The main recommendations of the study can be summarized as follows: efforts towards the developments of exporting structure either total or agricultural foreign trade are necessary. This can be achieved through adopting of a clear plan towards this target and to increase the Arab foreign trade between the Arab countries, either the total or the agricultural trade can be considered a major target also. Coordination between the Arab countries in the area of production and the specialization of specific agricultural and non-agriculture are also required. As well as productions in one or more Arab countries should be enhanced. That has relative advantages and hence the advantages of production and marketing efficiencies can be achieved.

\section{Recommendations}

Based on the findings and conclusions of last section, this study recommends several recommendations as following:

1. Coordination between Arab countries is required in the areas of production, and specialization in the production of certain products agricultural and non-agricultural. As several Arab countries have a comparative advantage in production, and are placing agricultural policies in this direction. Through this specialization and the division of labor between the Arab countries could be eased by competition in Arab markets and it will also help in upgrading the standards of efficiency, productivity, marketing surpluses and net exports of Arab world.

2. Development of infrastructure is necessary for the emergence of and to expand the scope of the exchange in intra-Arab trade. That includes communications, transport, ports, the network of roads between the Arab countries, the development of methods of land transport, sea transport and air transport. These are the most important tools for development of inter-Arab trade that needs for integrated information based on the branches of production in different Arab countries' production capacities and capabilities of the expansion in the short and medium terms. That should available to the business community in the Arab States.

3. Strengthening legal and institutional construction are very necessary for economic integration, for the establishment of specialized department for Great Arab Free Trade Area in every Arab country and to find effective authority over the authority of an independent state in the framework of the Economic and Social Council 
that can ensure fulfillment of obligations by Member States in the implementation of the agreements and decisions taken, and that are also working to remove all non-tariff restrictions and obstacles.

4. Speeding up the pace of establishing the customs union between the Arab countries is required. So that there is a unified tariff for all member States in the area of free trade with the outside world, and to make nontariff restrictions clearer and more transparent in order to harmonization of laws and regulations applicable in each Member State.

5. Better coordination of economic policies is required among member states. That can guarantee the freedom of movement of goods, people and capital. That is coincided by a sound environment in the region and by linking the domestic financial markets with global financial markets.

\section{References}

[1] Soliman, S.A.A. (2014) Economies of Foreign Agricultural Arab Trade. Ph.D. Thesis, Faculty of Agriculture, University of Kafr El-Sheikh, Egypt.

[2] Kona (2009) Riyad Persians: Arab Economic Integration Reality and Ambition. University of Kuwait, Kuwait.

[3] Arab Organization for Agricultural Development, the Secretariat of the League of Arab States, the Department of Economic Affairs (1994) Agricultural Trade Environmental Arab Methods Proposed for Their Development. Conference of the Arab Economic and Social Sciences Agricultural, Beirut, 1994.

[4] The League of Arab States, the Secretariat of the League of Arab States, the Department of Economic Affairs, Unified Arab Economic Report, Cairo, 2011.

[5] Bolbol, A.A. and Fatheldin, A.M. (2005) Intra-Arab Exports and Direct Investment an Empirical-Arab Monetary, Fund-Abu-Dhabi.

[6] Liman, I. and Abdalla, A. (1998) Inter-Arab Trade and Potential “Success of AFTA”. The Arab Planning Institute. 